\title{
Individual, species and geographic origin influence on cooperage oak extractible content (Quercus robur L. and Quercus petraea Liebl.)
}

\author{
F. Doussot ${ }^{1}$, P. Pardon ${ }^{*}$, J. Dedier ${ }^{2}$, B. De Jeso ${ }^{1}$ \\ ${ }^{1}$ Institut du Pin, ${ }^{2}$ Laboratoire de Chimie des Substances Végétales (LCSV) \\ Université Bordeaux I, 351 cours de la Libération, 33405 Talence Cedex, France
}

\begin{abstract}
Dry extract, ellagitanins, free ellagic acid, whisky-lactone, eugenol and vanillin have been quantified for a sample set of 61 pedunculate oaks (Quercus robur L.) and 72 sessile oaks (Quercus petraea Liebl.) originating from 6 different forests. Despite a very high interindividual variability, pedunculate oak shows higher level of dry extract, ellagitanins and free ellagic acid but lower level in volatil compounds compared to sessile oak. Inside a same species, differences between forests are less marked. Extractible compounds level is poorly correlated to the grain (ring width). Regarding cambial age, it might have its significance but lack of scientific data could not permit to conclude in that sense. Our results suggest that cooperage oak selection should be based on a species-provenance combination rather than on the grain or the provenance solely.
\end{abstract}

Keywords. Oak - extractible - species - variabilty.

\section{Introduction}

Sessile oak (Quercus petraea Liebl.) and Pedunculate oak (Quercus robur L.) respectively cover 1.86 and 2.32 millions of hectares for a total of 4.2 millions of hectares in France. Thus, they are the two major species and consequently play an important role in the economy. Wood industry does not distinguish the two species, which are utilized for similar purposes. Among them, there is the oak barrel industry, which considerably increased in the last few years $[1,2]$. During that period of time, numerous research works focused on the extractives of oak heartwood used in wine cooperage. The most important and throughly studied extractives are the ellagitanins and volatile compounds such as $\beta$-methyl- $\gamma$-octalactone, better known as whisky-lactone, eugenol and vanillin $[3,4]$. Ellagitanins role in wine would be to protect the other constituents against oxidation [5]. The organoleptic properties of these molecules are, however, not well-established [6]. On the other hand, volatil compounds give specific and appreciated aroma such as coconut for the whisky-lactone, clove for eugenol, and vanilla for vanilline [7-8]. Whisky-lactone is the principal volatile compound of the non heat-treated oak wood [7]. Two isomers are present in both sessile and pedunculate oak, the cis (-) and trans (+) [9]. In an hydroalcoolic solution, the cis isomer is four times more odorant that the trans isomer [7].

Ellagitanins concentrations are usually greater in pedunculate oak than in sessile oak [10-16]. Nonetheless, no difference was found by Masson et al. [12] when analyzing a sample of six trees per species. On another hand, odorant volatile compounds, principally whisky-lactone [7-10,13,14,16] are in greater concentrations in sessile oak than in pedunculate oak. Whichever molecules quantified, authors agree on the importance of interindividual variability. Other studies showed significant differences between various origins of french oak-woods $[7,17,18]$. But in most cases, the species was not known or remain non-mentioned.

The selection of oak wood for barrel making is based on two criteria: ring width (grain) [19,20] and geographic origin. For wine cooperage, one looks for slow growing oaks, which exhibit a tight grain because it is assumed they give appreciated volatil compounds and less tanins [20]. The goal of this study is to verify the respective influence of the individual tree variability, the species and the geographic origin using a 133 trees set arising from six forests, most of them having never been studied.

\section{Materials and methods}

\section{Wood sample origin and preparation}

The 133 trees are distributed among two species (61 pedunculate and 72 sessile) and six geographic origins. The species identification is carried out in winter based on morphological criteria (bark, leaves pedoncules collected on soil...). Populations were choosen according to species purity. Any forest or plots suspected to contain the two 
Table I. Origin and caracteristics of trees.

\begin{tabular}{lccccc}
\hline Origin & Codification & Species & $N^{1}$ & $\begin{array}{c}\text { Ring } \\
\text { width }\end{array}$ & Age $^{3}$ \\
\hline Dordogne & Dordogne1 & pedunculate & 23 & 3 & $75-120$ \\
Dordogne & Dordogne2 & pedunculate & 13 & 2.6 & $75-120$ \\
Pyrénées atlantiques & P.A & pedunculate & 25 & 2.6 & $80-120$ \\
Cher & Centre1 & sessile & 24 & 2.9 & $60-120$ \\
Indre et Loire & Centre2 & sessile & 24 & 1.2 & 220 \\
Saône et Loire & Bourgogne & sessile & 24 & 3.1 & $60-110$ \\
\hline
\end{tabular}

${ }^{1}$ number of trees

${ }^{2}$ ring width $(\mathrm{mm})$; average of all trees per origin

3 tree age (years)

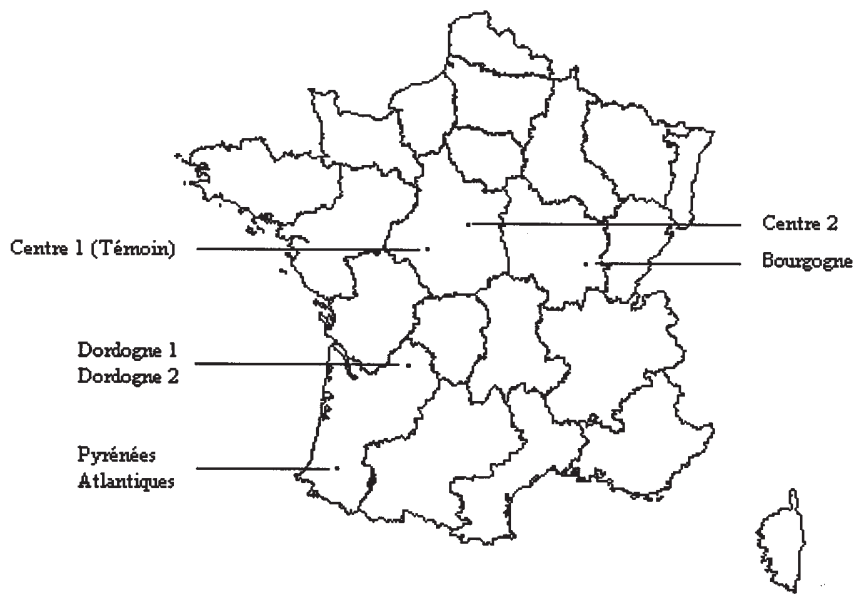

Figure 1. Geographic origin of the six french forests.

species are not kept for the study. Five origins are provided by private forests whereas the sixth one (Centre 2) raised from domanial forest of Loches. Table I and figure 1 show the six origins, the number of trees, annual ring, width and age of trees. Trees were cut during the 1997-1998 winter. 5 to $6 \mathrm{~cm}$ thick slices were cut in the tree trunk at $50 \mathrm{~cm}$ high from the ground. The wood is refrigerated at $5{ }^{\circ} \mathrm{C}$ under vacuum in sealed bag after being cut in samples. For each slice, four wood samples, two by two opposed, were cut $(2.5 \mathrm{~cm}$ large; $4 \mathrm{~cm}$ thick), they correspond to the region -25 to -40 years (variable length). The wood was milled and the sawn from the four samples was mixed and sieved in order to only keep particles smaller than $250 \mu \mathrm{m}$. The sawn is then frozen down to $-18{ }^{\circ} \mathrm{C}$. Two months were needed between cutting down and sawn storing. Quantification is therefore carried out on fresh timber. The annual ring width is determined by measuring the length between rings -25 and -40 years and dividing it by 15 . The average over the four samples of each tree is then calculated in order to obtain the individual tree value. The last parameter taken into account is the sapwood, which is visible for oakwood. The slice is used to measure the number of years of the sapwood.

\section{Dry extract, ellagitanins and free ellagic acid quantification}

The sawdust samples ( $5 \mathrm{~g}$ ) were extracted for 16 hours by $250 \mathrm{ml}$ of an acetone-water mixture $(7 / 3 \mathrm{v} / \mathrm{v})$ under magnetic stirring in darkness and at $23{ }^{\circ} \mathrm{C}$. After filtration, the solvant is removed in a rotary evaporator at $50{ }^{\circ} \mathrm{C}$. The dry extract value is expressed in $\mathrm{mg} / \mathrm{g}$ of dry wood corrected by the sawdust humidity. Quantitative determination of ellagitanins complies with the method described by Peng et al. [20]. It implies an acidic hydrolysis followed by the HPLC determination of the ellagic acid produced. $20 \mathrm{mg}$ of dry extract were dissolved in $10 \mathrm{ml}$ of methanol-aqueous $\mathrm{HCl}$ $(6 \mathrm{~N})$. Free ellagic acid naturally present in oakwood is determined before hydrolysis. The solution was then placed in a teflon sealled glass vial. Hydrolysis is carried out during 160 minutes at $120{ }^{\circ} \mathrm{C}$ in an oil bath. All solutions were filtered on $0.45 \mu \mathrm{m}$ Millipore membrane prior to injection. The difference in the values correspond to the ellagitanins that have liberated ellagic acid upon hydrolysis. Results are calculated using a calibration curve and expressed as castalagin equivalent on the basis that 1 mole of ellagic acid correspond to 1 mole of castalagin. Ellagic acid peak identification is confirmed by its retention time and UV spectrum comparison with a standard solution of ellagic acid (Fluka $98 \%$ by HPLC).

\section{Quantification}

Chromatographic conditions were as follows: HPLC pump P 4000, autosampler AS 3000, UV detector UV 2000 (ThermoSeparation Products). Column lichrospher $100 \mathrm{RP} 18$ (250 mm; $4.6 \mathrm{~mm} ; 5 \mu \mathrm{m})$. Injection volume: $20 \mu$ l. Flow: $1 \mathrm{ml} / \mathrm{mn}$. Mobile phase, Solvent A: $\mathrm{H}_{2} \mathrm{O} / \mathrm{H}_{3} \mathrm{PO}_{4}$ (990: 1); Solvent B: Methanol/ $/ \mathrm{H}_{3} \mathrm{PO}_{4}$ (990: 1). Linear gradient 0 to $100 \% \mathrm{~B}$ in 20 minutes. Detection wavelength: $370 \mathrm{~nm}$.

\section{Whisky-lactone, eugenol and vanillin quantification}

The sawdust samples ( $2 \mathrm{~g}$ ) were extracted for 16 hours by $60 \mathrm{ml}$ of an ethanol/water mixture (7/3) under magnetic stirring and at $23{ }^{\circ} \mathrm{C}$. The solvent was spiked with $100 \mu \mathrm{g}$ of 3-octanol (internal standard) by adding $1 \mathrm{ml}$ of a standard solution $(100 \mathrm{mg} / \mathrm{l}$ of 3 -octanol in ethanol). The extract was then filtered and dilued in water down to $200 \mathrm{ml}$. A three step liquid-liquid extraction was then carried out using 25, $15,10 \mathrm{ml}$ of a diethyl ether-hexane mixture (1/1) under magnetic stirring for 10 minutes each. The three organic phases are mixed together, dried over anhydrous sodium sulphate then transferred in a conical vial. The solution was slowly concentrated down to $2 \mathrm{ml}$ at $35{ }^{\circ} \mathrm{C}$ under nitrogen stream. Identification and quantification were carried out by comparison with a synthetic solution containing the three standard molecules (whisky-lactone, eugenol and vanillin) and having been extracted with the same protocol. 


\section{Original articles}

\section{Quantification}

GC and autosampler are Fisons respectively GC 8000 series and AS 800 equipped with a Carbowax $20 \mathrm{M}$ capillary column (SGE $50 \mathrm{~m} ; 0.22 \mathrm{~mm} ; 0.25 \mu \mathrm{m}$ ). Operating parameters were as follows: carrier gas is helium at $130 \mathrm{kPa}$; injector is used in the splitless mode (30 s closing time); temperature detector and injector: $220{ }^{\circ} \mathrm{C}$; injection volume: $2 \mu \mathrm{l}$; oven temperature: $40{ }^{\circ} \mathrm{C} / 1 \mathrm{~min}$ isotherm $/ / 2{ }^{\circ} \mathrm{C} / \mathrm{min}$ up to $220{ }^{\circ} \mathrm{C} / / 220{ }^{\circ} \mathrm{C}, 20 \mathrm{~min}$ isotherm.

\section{Repeatability and statistical analyses}

Extraction, hydrolysis, injection and integration variations were calculated using 5 repetitions of the same wood sample. Averages, standard deviations and variation coefficient are calculated. Variance analyses and PCA are carried out with SPSS 10.05 software on the gross values.

\section{Results}

Table II shows variation coefficient obtained for each compound in the repeatability test.

\section{Dry extracts, ellagitanins and free ellagic acid}

Values for dry extract, ellagitanins and ellagic acid vary respectively from 60.4 to $303.1 \mathrm{mg} / \mathrm{g} ; 21.1$ to $154.7 \mathrm{mg} / \mathrm{g}$ and 1.8 to $10.2 \mathrm{mg} / \mathrm{g}$. Within the same provenance and same species, variability is great. Based on the good repeatability

Table II. Repetability test for each compounds.

Dry Ellagitanins Cis Trans Eugenol Vanillin
extract

coefficient of

variation $(\%)$

0.9

1.9

3.

$\begin{array}{lll}3.2 & 4.4 & 7.8\end{array}$

test results, variability can be attributed to inter-individual variation which can be extremely high (Tab. III and IV). Variance analysis results show that species differences are significant. The three parameters appear to be higher for pedunculate oak than for sessile oak with respectively $21.5 \%$ and $18.1 \%$ for dry extract, 10 and $8.2 \%$ for ellagitanins relative to wood weight. These values are slightly higher than those found in literature $[12,16]$ but explanation can be found in the sampling protocol. Indeed the analyzed wood zone (rings -25 to -40 years) corresponds to the most recent heartwood which is potentially very rich in ellagitanin [12,21]. For the three parameters, sessile oak appears to give the greatest variability in our sample.

The highest values found for dry extract, ellagitanins and ellagic acid are arising from provenance composed with pedunculate oak (Tab. IV) and are significantly different

Table III. Influence of species on extract content.

\begin{tabular}{lcc}
\hline & $\begin{array}{c}\text { Pedunculate } \\
\text { 61 trees }\end{array}$ & $\begin{array}{c}\text { Sessile } \\
72 \text { trees }\end{array}$ \\
\hline dry extract $(\mathrm{mg} / \mathrm{g})$ & $\mathbf{2 1 4 . 6}(15.9)$ & $\mathbf{1 8 1 . 4}(21.4)$ \\
& {$[144.6-303.1]$} & {$[60.4-302.2]$} \\
ellagitanins $(\mathrm{mg} / \mathrm{g})$ & $\mathbf{8 0 . 8}(21.4)$ & $\mathbf{6 7 . 3}(27.6)$ \\
& {$[49.8-126.7]$} & {$[17.2-110.6]$} \\
ellagic acid $(\mathrm{mg} / \mathrm{g})$ & $\mathbf{5 . 0}(18.1)$ & $\mathbf{4 . 2}(32.7)$ \\
& {$[2.7-7.8]$} & {$[1.4-8.4]$} \\
whisky-lactone $(\mu \mathrm{g} / \mathrm{g})$ & $\mathbf{2 . 2}(161.8)$ & $\mathbf{3 5 . 8}(96)$ \\
& {$[0.1-18.5]$} & {$[0.4-213.9]$} \\
cis $(\%)$ & $\mathbf{6 9 . 7}$ & $\mathbf{7 4 . 8}$ \\
trans $(\%)$ & $\mathbf{3 0 . 3}$ & $\mathbf{2 5 . 2}$ \\
eugenol $(\mu \mathrm{g} / \mathrm{g})$ & $\mathbf{1 . 9}(63.3)$ & $\mathbf{3 . 8}(79.6)$ \\
& {$[0.2-5.5]$} & {$[0.6-21.4]$} \\
vanillin $(\mu \mathrm{g} / \mathrm{g})$ & $\mathbf{1 2 . 5}(31.7)$ & $\mathbf{1 4 . 4}(30.9)$ \\
& {$[6.4-27.3]$} & {$[4.2-23]$} \\
\hline
\end{tabular}

In bold: mean

( ): coefficient of variation

[ ]: minimum and maximum

Table IV. Influence of provenance on extract content.

\begin{tabular}{lcccccc}
\hline & $\begin{array}{c}\text { Dordogne1 } \\
\text { Pedunculate } \\
23 \text { trees }\end{array}$ & $\begin{array}{c}\text { Dordogne2 } \\
\text { Pedunculate } \\
13 \text { trees }\end{array}$ & $\begin{array}{c}\text { P.A } \\
\text { Pedunculate } \\
25 \text { trees }\end{array}$ & $\begin{array}{c}\text { Centre1 } \\
\text { Sessile } \\
24 \text { trees }\end{array}$ & $\begin{array}{c}\text { Centre2 } \\
\text { Sessile } \\
24 \text { trees }\end{array}$ & $\begin{array}{c}\text { Bourgogne } \\
\text { Sessile } \\
24 \text { trees }\end{array}$ \\
\hline dry extract $(\mathrm{mg} / \mathrm{g})$ & $\mathbf{2 1 8 . 6}(17.8)$ & $\mathbf{2 3 4 . 2}(12.5)$ & $\mathbf{2 0 0 . 6}(12.8)$ & $\mathbf{1 8 9 . 1}(15.3)$ & $\mathbf{1 7 1 . 1}(31.3)$ & $\mathbf{1 8 4 . 3}(14.6)$ \\
ellagitanins $(\mathrm{mg} / \mathrm{g})$ & $\mathbf{1 0 1 . 9}(21.1)$ & $\mathbf{1 1 0 . 2}(20.5)$ & $\mathbf{8 9 . 8}(18.4)$ & $\mathbf{8 8 . 7}(20.9)$ & $\mathbf{7 1 . 8}(39.8)$ & $\mathbf{8 6 . 2}(18.4)$ \\
ellagic acid $(\mathrm{mg} / \mathrm{g})$ & $\mathbf{6 . 4}(20.3)$ & $\mathbf{6}(13.8)$ & $\mathbf{5 . 8}(17.1)$ & $\mathbf{6 . 1}(29.5)$ & $\mathbf{4 . 5}(37.4)$ & $\mathbf{5 . 4}(24.7)$ \\
W-lactone $(\mu \mathrm{g} / \mathrm{g})$ & $\mathbf{1 . 6}(145.6)$ & $\mathbf{2 . 9}(176.2)$ & $\mathbf{2 . 4}(150.3)$ & $\mathbf{2 8 . 5}(82.3)$ & $\mathbf{5 5}(82.1)$ & $\mathbf{2 3 . 9}(90.9)$ \\
cis $(\%)$ & $\mathbf{6 9 . 2}$ & $\mathbf{6 9 . 9}$ & $\mathbf{7 0 . 1}$ & $\mathbf{7 0 . 9}$ & $\mathbf{8 0 . 2}$ & $\mathbf{7 3}$ \\
trans $(\%)$ & $\mathbf{3 0 . 8}$ & $\mathbf{3 0 . 1}$ & $\mathbf{2 9 . 9}$ & $\mathbf{2 9 . 1}$ & $\mathbf{1 9 . 8}$ & $\mathbf{2 7}$ \\
eugenol $(\mu \mathrm{g} / \mathrm{g})$ & $\mathbf{1 . 6}(69.3)$ & $\mathbf{1 . 9}(53.7)$ & $\mathbf{2 . 2}(61.5)$ & $\mathbf{4}(52.8)$ & $\mathbf{4 . 5}(98.8)$ & $\mathbf{2 . 9}(55.8)$ \\
vanillin $(\mu \mathrm{g} / \mathrm{g})$ & $\mathbf{1 2 . 6}(33.7)$ & $\mathbf{1 0 . 7}(22)$ & $\mathbf{1 3 . 3}(31.3)$ & $\mathbf{1 3 . 1}(26.9)$ & $\mathbf{1 3 . 6}(36.4)$ & $\mathbf{1 6 . 6}(25)$ \\
& & & & & & \\
\hline
\end{tabular}

In bold : mean

( ): coefficient of variation 
Table V. Analysis of variance with one factor (species or provenance).

\begin{tabular}{|c|c|c|c|c|}
\hline & $\begin{array}{l}\text { F Species } \\
\text { df: } 1.132\end{array}$ & $\begin{array}{l}\text { globality } \\
\text { df: } 5.127\end{array}$ & $\begin{array}{l}\text { F Provenance } \\
\text { pedunculate } \\
\text { df: } 2.58\end{array}$ & $\begin{array}{c}\text { sessile } \\
\text { df: } 2.69\end{array}$ \\
\hline dry extract & $27.01(<0.0005)$ & $7.997(<0.0005)$ & $5.017(0.01)$ & $1.43(0.246)$ \\
\hline ellagitanins & $18.556(<0.0005)$ & $7.795(<0.0005)$ & $5.021(0.01)$ & $4.295(0.17)$ \\
\hline ellagic acid & $12.01(0.001)$ & $6.164(<0.0005)$ & $1.547(0.222)$ & $5.924(0.004)$ \\
\hline total lactone & $57.606(<0.0005)$ & $18.141(<0.0005)$ & $0.623(0.54)$ & $6.62(0.002)$ \\
\hline cis lactone & $42.616(<0.0005)$ & $14.648(<0.0005)$ & $0.435(0.649)$ & $6.616(0.002)$ \\
\hline trans lactone & $21.326(<0.0005)$ & $4.572(0.0001)$ & $0.896(0.414)$ & $0.51(0.603)$ \\
\hline eugenol & $21.275(<0.0005)$ & $5.699(<0.0005)$ & $1.49(0.234)$ & $1.848(0.165)$ \\
\hline vanillin & $7.011(0.009)$ & $4.231(0.001)$ & $1.908(0.158)$ & $4.713(0.012)$ \\
\hline
\end{tabular}

( ): level of significance

with provenance based on sessile oak. However, P.A. and Centre 1 do not show any difference, the latter exhibiting high value for free ellagic acid.

\section{Volatile compounds}

Concentration variations for vanillin, eugenol and whiskylactone are respectively 4.2 to $27.3 \mu \mathrm{g} / \mathrm{g} ; 0.2$ to $21.4 \mu \mathrm{g} / \mathrm{g}$ and 0.1 to $213.9 \mu \mathrm{g} / \mathrm{g}$. Extreme value amplitude for whiskylactone is over 2000. This variability can be attributed to interindividual variation.

Sessile oak is significantly more rich in volatile compounds than pedunculate oak. Differences are only slight for vanillin compared to eugenol and even more to whisky-lactone. A factor of 2 is found for eugenol and 16 for whiskylactone (Tab. III). Between sessile oak and pedunculate oak, the whisky-lactone enantiomeric ratio is however species independent. The cis stereoisomer being predominant. Nonetheless variability of this ratio is great and in some cases, trans configuration is in greater concentration than the cis one. Variability predominance of whisky-lactone is for pedunculate oak and eugenol for sessile oak.

Provenance with high level of whisky-lactone and eugenol are all with sessile oak. In the case of vanillin, differences between pedunculate and sessile provenance are often non-significant. Centre 2 provenance strongly differs from other provenance not only by its low level of nonvolatile compounds and high concentration of lactone and eugenol but also by the age of the trees and the annual ring width. As for non-volatile compounds, differences between provenance of identical species are less significant than those between species.

\section{Ring width and age influence}

Statistical influence of ring width has been eliminated by introducing the parameter as covariable. For a given ring width, species and provenance effects remain significant with a very small modification of $F$ values (results not presented). On the contrary, covariance analysis using the age changes some results. For a given age, one observes a
Table VI. Analysis of covariance with one factor (provenance) and age as a covariate.

\begin{tabular}{lcc}
\hline & $\begin{array}{c}\text { F age } \\
\text { df: } 1.71\end{array}$ & $\begin{array}{c}\text { F sessile } \\
\text { df: } 1.71\end{array}$ \\
\hline dry extract & $0.345(0.589)$ & $0.134(0.875)$ \\
ellagitanins & $0.646(0.424)$ & $0.115(0.892)$ \\
ellagic acid & $2.588(0.112)$ & $0.902(0.410)$ \\
total lactone & $0.311(0.579)$ & $0.861(0.47)$ \\
cis lactone & $0.316(0.576)$ & $0.823(0.443)$ \\
trans lactone & $0.02(0.888)$ & $0.111(0.895)$ \\
eugenol & $0.029(0.865)$ & $0.964(0.386)$ \\
vanillin & $1.897(0.173)$ & $5.304(0.007)$ \\
\hline
\end{tabular}

( ): level of significance

general decrease for the majority of the variables of the $\mathrm{F}$ "species" value (see Tab. V) which nonetheless remain significant. The same tendency can be found for the provenance effect (results not shown) and no change can be observed for the origin of pedunculate oaks. The provenance effect is no longer significant for ellagic acid, lactone content and cis lactone in sessile oaks (see Tab. VI). These results suggest that the provenance effect for sessile oak originate, in our sample, from an age effect, which also explains part of the variability in between species.

\section{Multivariables analyses}

Principal component analysis hightlights strong correlations between, on one hand, lactone content, cis lactone and eugenol and on the other hand dry extract, ellagitanins and free ellagic acid (Fig. 2). The ring width is only slightly correlated with the other variables. Projection of the 133 individuals in the 1-2 factorial plan (Fig. 3), which explains $57 \%$ of the total variability, allows a partial distinction of the two species along component 1 which is strongly and positively correlated with whisky-lactone (total and cis) and eugenol. Component 2, which corresponds to non-volatile compounds, discriminates only slightly the two species. For 


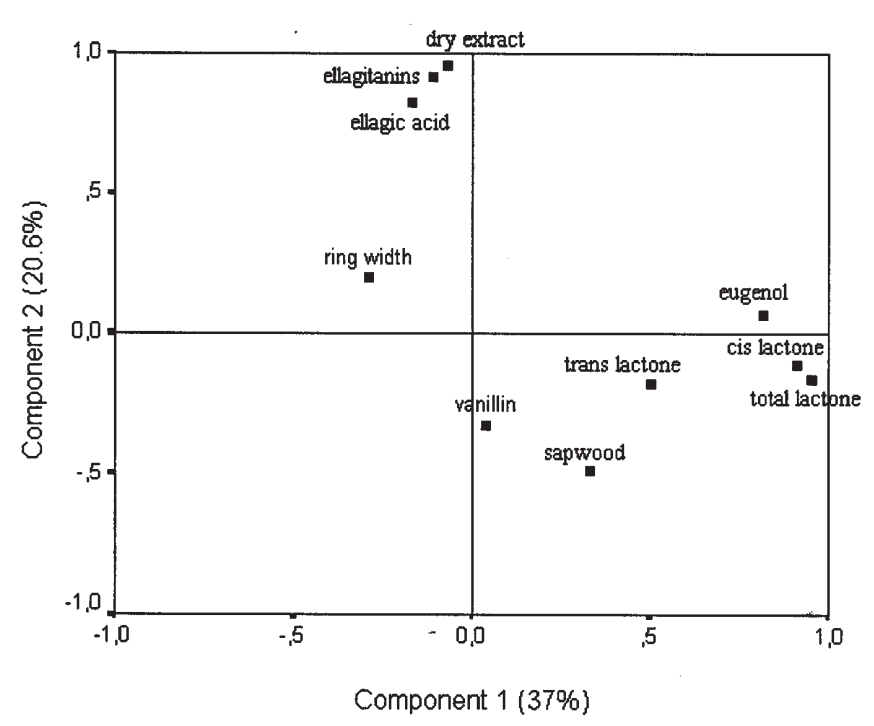

Figure 2. PCA - Projection of the 10 variables in the 1-2 factorial.

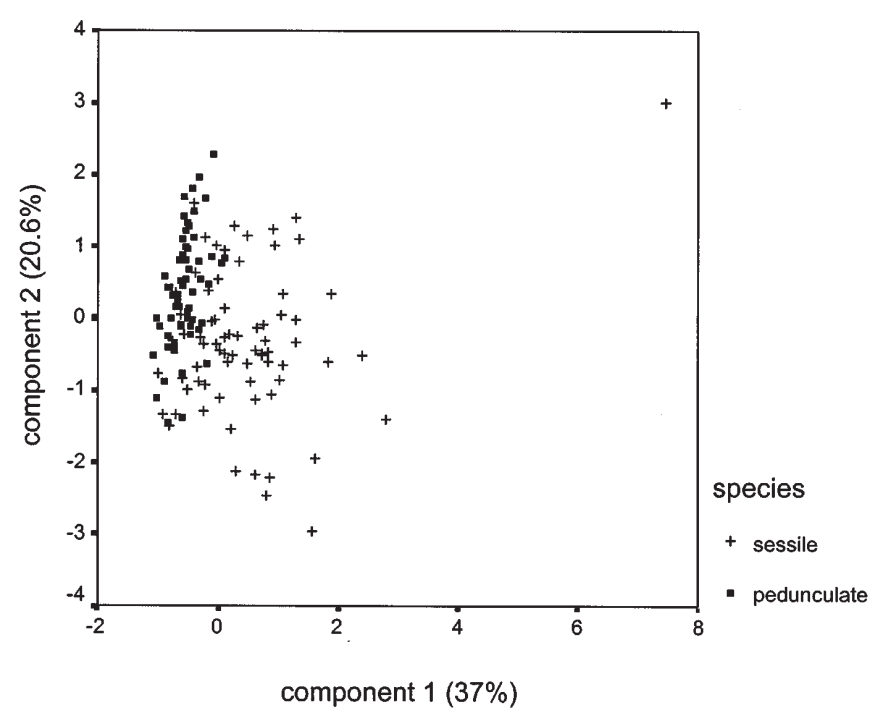

Figure 3. PCA - Projection of the 133 individuals in the 1-2 factorial plan.

given non-volatile compound concentration, pedunculate oak is poorer in volatile compounds than sessile oak. It must be pointed as an outliner. This tree coming from Centre 2 exhibits the strongest values for dry extract, ellagitanins, whisky-lactone and eugenol (respectively $302.2 \mathrm{mg} / \mathrm{g}$, $135.1 \mathrm{mg} / \mathrm{g}, 213 \mu \mathrm{g} / \mathrm{g}$, and $21.4 \mu \mathrm{g} / \mathrm{g}$ ). This individual can be qualified as off standard or aberrant. The ring width is remotely correlated with the other wood chemical characteristics.

\section{Discussion}

In agreement with previous works, pedunculate oak is, in average, richer in extractibles and ellagitanins and poorer in volatile compound than sessile oak. The inter-individual variability is tremendous whatever compound quantified. It can therefore have more differences between two individuals of the same species and the same forest than between the statistical averages of the two species. This fact shows the necessity to possess a great number of individuals to be able to measure effect arising from species and provenance. This high inter-individual variability consequently prevents species determination based on these chemical parameters. Although mean deviations between species are the highest for whisky lactone, its variability remains also very high. A large set of sessile oaks shows whisky-lactone content lower than the average found for pedunculate oaks. Multivariable analysis does not allow full discrimination of species and provenance.

In our sample set, there are greater differences between species than between provenance of the same species. Thus, a great part of the provenance variability is due to the species effect when the species is not taken into account. This characteristic can explain, when species is unknown, the large offsets measured by several authors $[7,17,18]$ between different oak origins. The small differences between provenance of a same species cannot be extended. Indeed, in our study, the geographic distances between forests of a same species were relatively small compared to the surface covered by the two species. That could explain the quasi homogeneity of the chemical characteristics. On large distances, differences could be much greater. These results suggest that it could be reasonable to partition geographical zones where cooperage oaks would obviously be taken into account. To define such zones, a much larger set of points per origin would be necessary.

Results of covariance analysis suggest that tree ageing favour production of volatile compounds such as whisky-lactone and eugenol. Nevertheless, conclusion should not be drawn too quickly due to the lack of bibliographic data. Indeed, characteristics of Centre 2 origin could be explained more by genetic or environmental parameters than by the cambial age of the tree.

Differences between species and provenance do not arise from tree growth speed differences. The only slight correlation of ring width and extractibles do not allow using these parameters to monitor oak chemical quality. To conclude, cooperage oak selection must be based on a combination of species-provenance rather than on the grain $[19,20,22,23]$ or the provenance only $[7,18]$.

\section{Conclusion}

Significant differences are observed for extractibles content between sessile and pedunculate oaks. For a same species, provenance differences are, in our sample set, less marked. The great inter-individual variability does not allow to totally 
discriminate the two species. Consequently, species cannot be solely and totally determined with the chemical characteristics.

Our study results are not in agreement with actual quality criteria used in cooperage industry. Ring width appears to be only slightly correlated to extractives content and geographic origin is, on its own, insufficient. Indeed, apart from Limousin, and Pyrénées-Atlantique regions, the two species are present in all the major supply sources for cooperage oaks (Centre France, Bourgogne, Vosges...). These data show that oak selection should be based on a combinaison of species-provenance criteria. Since, only fresh timber has been concerned by this study, it is therefore, too early for a definitive conclusion. Variation of these results will have to be monitored during wood natural drying, cask heating and wine cooperaging. Studies are being carried out to answer to such question. Finally, field application of such conclusion can turn out to be rather difficult because individuals might exhibit intermediate morphological characteristics, which would not ease species determination.

\section{Acknowledgments}

We would like to thank Sylvain Coopers, C.R.P.F Aquitaine and Stéphane Quideau for his advises. This work was supported by a grant from Région Aquitaine and DRAF Aquitaine (PDZR).

\section{References}

1. Husson, H.; Capdevielle, P. Revue des CEnologues 2000, 94, 1-6.

2. Lacroix, J.P. Actes du Colloque Sciences et Techniques de la Tonnellerie 1998, 4, 9-16.

3. Masson, G.; Puech, J.-L.; Moutounet, M. Bulletin de L'O.I.V. 1996, 635-657.
4. Masson, G.; Puech, J.-L.; Baumes, R.; Moutounet, M. Revue des Enologues 1997, 82, 20-23.

5. Vivas, N.; Glories, Y. Am. J. Enol. Vitic. 1996, 47, 103-107.

6. Pocock, K.F.; Sefton, M.A.; Williams, P.J. Am. J. Enol. Vitic. 1994, 45(4), 429-434.

7. Chatonnet, P. Thesis, University of Bordeaux II, 1995, 269 p.

8. Vivas, N.; Bourgeois, G.; Saint-Cricq de Gaulejac, N.; Glories, Y. Analusis 1997, 25(6), 19-23.

9. Masson, G.; Guichard, E.; Fournier, N.; Puech, J.-L. Am. J. Enol. Vitic. 1995, 46(4), 424-428.

10. Mosedale, J.R.; Savill, P.S. Forestry 1996, 69(1), 47-55.

11. Scalbert, A.; Monties, B.; Dupouey, J-L.; Becker, M. Bull. Groupe Polyphénols 1986, 13, 615-619.

12. Masson, G.; Puech, J.-L.; Moutounet, M. Am. J. Enol. Vitic. 1995, 46(2), 262-268.

13. Feuillat, F. Thesis ENGREF, 1997, 400 p.

14. Mosedale, J.R.; Ford, A. J. Sci. Food Agric. 1996, 70, $273-$ 287.

15. Mosedale, J.R.; Charrier, B.; Janin, G. Forestry 1996, 69(2), 111-124.

16. Mosedale, J.R.; Feuillat, F.; Baumes, R.; Dupouey, J-L.; Puech, J.-L. Can. J. For. Res. 1998, 28, 1-23.

17. Fernandez de Simon, B.; Cadahia, E.; Conde, E.; GarciaVallejo, M.C. Holzforschung 1999, 53, 147-150.

18. Marco, J.; Artajona, J.; Larrechi, M.S.; Rius, F.X. Am. J. Enol. Vitic. 1994, 45(2), 192-200.

19. Feuillat, F.; Keller, R.; Huber, F. Revue Française d'Enologie 1992, 139, 65-69.

20. Vivas, N. Actes du Colloque Sciences et Techniques de la Tonnellerie 1995, 1, 17-32.

21. Peng, S.; Scalbert, A.; Monties, B. Phytochemistry 1991, 30(3), 775-778.

22. Feuillat, F.; Keller, R.; Huber, F. Revue des Enologues 1998 87, 11-15.

23. Feuillat, F.; Keller, R.; Huber, F. Revue des Enologues 1998, $88,30-32$ 